\title{
ISONIAZID IN LEPROSY TREATMENT
}

A. GarretT, M.B., M.R.C.S., L.R.C.P.

\author{
Area Superintendent, Onitsha Province, East Nigeria
}

It has been adequately shown by others that Isoniazid alone is not satisfactory in the treatment of leprosy. The purpose of this experiment was to find out whether it has any adjuvant action when used with Dapsone, which appears to be the most satisfactory drug all round.

For this purpose, a group of difficult patients were taken. The difficulties were either slowness or absence of bacteriological improvement or very obstinate reactions. All cases chosen were lepromatous.

From August, I952, to July, I953, a dose of about $3 \mathrm{mg}$. per kg. daily was given, after which I was advised by Dr. R. G. Cochrane to raise it to $6 \mathrm{mg}$. per $\mathrm{kg}$. daily. This was done.

Routine smears are taken from three places and graded I to $4^{+}$, so that a maximum Bacteriological Index (B.I.) of $\mathrm{I} 2$ is obtained.

In recording the B.I. of each patient, I have selected smear results from a long list to illustrate the general trend, taking the highest recorded B.I.s during the period rather than the occasional lower ones which may have been mistaken.

The exception of this rule is $Z / 1652$. I have recorded the last seven smears in full as I fear the development of drug resistance in his case.

Clinically, results are estimated by skin thickenings and erythema and by frequency and severity of reactions.

The experiment shows bacteriological improvement in all but one case and clinical improvement in all cases.

My opinion is that the improvement is more rapid than could be expected of Dapsone alone, but the difference is not very marked. Dapsone alone is so successful in the vast majority of our patients that the great addition to expense in buying Isonaizid and to staff time in giving daily treatment is not warranted for routine work. There are, however, the few for whom it appears that this additional treatment is of great value.

The selection of male patients for this experiment is purely because they were the ones whose leprosy was difficult to treat. 
I am indebted to various firms, specially Messrs. Boots, who helped me by providing Isoniazid at first and later to Dr. Cochrane who arranged for further supplies and gave me advice and encouragement.

Z/93. P.E. Male. 35 years. According to the patient he had three flat macules in 1932. He had Hydnocarpus treatment for I I years and was discharged in 1943. In 1944, he was admitted here with diffuse leproma, had further hydnocarpus treatment, but steadily developed deformities. In August, r949, he was put on Sulphetrone and in November, 1950, on twice weekly Dapsone. He was subject to numerous lepra reactions on both Sulphetrone and Dapsone and his treatment had to be reduced to roo mg. Dapsone twice weekly. In December, 1952, he was put on Dapsone as before plus Isoniazid $200 \mathrm{mg}$. daily. In September, I953, he was much better, could take Dapsone $300 \mathrm{mg}$. twice weekly. In June, 1955, he is taking Dapsone $400 \mathrm{mg}$. and his general condition and handgrip have improved.

$$
\text { Bacteriological. } \begin{array}{rcc}
4.47 & \text { B.I. } & 8 \\
\text { ro. } 54 & \text {, } & 3
\end{array}
$$

Z/51. V.I. Male. 35 years. In September, 1939, he had a very severe Nodular Leproma. Under hydocarpus oil his condition improved and smears became negative, but relapsed while still on treatment. In February, 1949, he had widespread new nodules. In August, I949. Sulphetrone was started and in November, 1950, twice weekly Dapsone. In July, 1952, after three years of Sulphones he was much the same. He started Isoniazid. Since then his progress has been steady and slow. In June, I955, leprosy still appears active, with erythema and some thickening, but as smears have been twice negative, it is possible that these are only scars. $\mathrm{He}$ is an albino, so erythema is much easier to see.

\begin{tabular}{|c|c|c|}
\hline Bacteriological. & 8.48 & B.I. \\
\hline & $7 \cdot 52$ & ", \\
\hline & 8.53 & ", \\
\hline & I0.54 & ", \\
\hline & I 2.54 & , \\
\hline & I. 55 & $\because n$ \\
\hline
\end{tabular}

Z/1399. O.N. Male. 15 years. I943 leprosy started. In I946 he had a Nodular Leproma and started hydnocarpus oil. The leprosy remained highly active. In August, 1949, he started Sulphetrone and November, I950, Dapsone twice weekly, under which he improved clinically but had severe limb pains. His nerves were large. In August, I952, he started Isoniazid and his limb pains and clinical condition steadily improved.

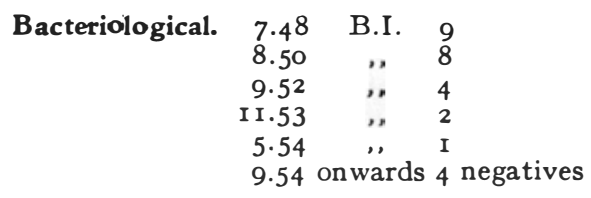

Z/1639. O.A. Male. 45 years. Had leprosy in 1936 with hydnocarpus treatment, but became worse. Came to Oji River in 1949 with severe nodular leproma and enlarged ulnar and popliteal nerves. April, I950, started Dapsone $200 \mathrm{mg}$. daily. November, 1950, $400 \mathrm{mg}$. twice weekly. He had very severe reactions. In December, I95I, he started Thiacetazone, but continued to have severe lepra reactions. In October, 1952, he started Isoniazid with Dapsone for two months, followed by the addition of Dapsone, which was increased with his tolerance of the drug, 
until in September, 1953, he could tolerate $400 \mathrm{mg}$. twice weekly without more than mild reactions.

$\begin{array}{rrrr}\text { Bacteriological. } & \text { ro.49 } & \text { B.I. } & 8 \\ 9.53 & \text {, } & 7 \\ \text { I.54 } & \text { "' } & 4 \\ \text { I } 2.54 & \text { ", } & 3\end{array}$

Z/1652. N.N. Male. 35 years. 1948 leprosy started on upper arm. In December, r949, he had infiltrated leproma with early nodules, swelling of legs and very enlarged external popliteal nerves and large ulnars. He had hydnocarpus oil for four months and started Dapsone $200 \mathrm{mg}$. daily in April, I950, and $400 \mathrm{mg}$. twice weekly in November, I950. He had many reactions and was given Thiacetazone in 1952 , but transferred to Isoniazid in October, 1952. He continued to have so many reactions that Dapsone was stopped in May, I953, and replaced by Thiacetazone in July 1953. In September, 1953, he started Dapsone again instead of Thiacetazone, and by July, 1954, he was able to take $400 \mathrm{mg}$. twice weekly. In June, I955, he still gets reactions in what appear to be localised lepromatous areas on the chest, but though his bacteriology in the last few months has shown a rise, clinically he seems better.

$\begin{array}{rrcc}\text { Bacteriological. } & \text { I2.49 } & \text { B.I. } & 9 \\ 3.54 & \text { " } & 3 \\ 5.54 & \text { "' } & \text { I } \\ 7.54 & \text { "' } & \text { O } \\ & \text { 10.54 } & \text { ". } & \text { I } \\ 6.55 & \text { " } & 4\end{array}$

Z/2124. O.E. Male. 14 years. March, I952, had leprosy for about one year, but had severe nodular leproma. He started Dapsone, but had many reactions and could only take very small doses. In November, I953. he started Isoniazid and his reactions improved shortly afterwards. He is now able to tolerate Dapsone $300 \mathrm{mg}$. twice weekly with very little trouble.

$\begin{array}{lccc}\text { Bacteriological. } & 3.52 & \text { B.I. } & 9 \\ 3.53 & \text { " } & 7 \\ 6.54 & \text { "' } & 3 \\ & 2.55 & \text { "' } & \text { I }\end{array}$

Z/2238. G.E. Male. 30 years. I950 extreme nodular leproma, had very severe' lepra reactions on twice weekly Dapsone and started Isoniazid in November, 1952. In September, 1953, he had a very severe left ulnar reaction and in July, I954, his right ulnar reacted severely. All the time he has had mild lepra and ulnar nerve reactions in addition but they are improving in June, 1955. He is able to tolerate Dapsone 2 twice weekly with few mild nerve reactions only.

\begin{tabular}{|c|c|c|c|}
\hline Bacteriological. & $5 \cdot 50$ & B.I. & I2 \\
\hline & 10.52 & ", & 4 \\
\hline & 8.53 & " & 5 \\
\hline & 6.54 & , & 3 \\
\hline I $2.54 \delta$ & 3.55 & , & o \\
\hline
\end{tabular}

Z/106. P.E. Male. 50 years. In 1948 he had diffuse and thickened leproma with very large ulnar and extension popliteal nerves. He had a year on hydnocarpus oil and in September, I949, started Sulphetrone. In November, 1950, he had Dapsone $400 \mathrm{mg}$. twice weekly. He had many ulnar nerve reactions with swelling of the hands, and had to reduce treatment to Dapsone roo mg. In October, 1952, he started Isoniazid. His reactions became less severe and by July, I954, he was able to take Dapsone $400 \mathrm{mg}$. twice weekly.

$\begin{array}{rrrl}\text { Bacteriological. } & 8.50 & \text { B.I. } & 7 \\ \text { I } 2.52 & \text { " } & 3 \\ \text { I I.53 } & \text { " } & 2 \\ 5.54 & \text { " } & \text { I } \\ & 7.54 \text { on wards } & 5 \text { negatives }\end{array}$


Z/1075. J.A. Male. 45 years. I935 leprosy started, I 940 he started hydnocarpus treatment with severe nodular leproma, early deformities and invasion of the eyes. There was no improvement in nine years, but the eyes and limbs deteriorated. In December, I949, he started Sulphetrone. In April, I950, daily Dapsone $200 \mathrm{mg}$. and in November, 1950, $400 \mathrm{mg}$. twice weekly. He had repeated reactions until August, 1952, when he started Isoniazid. Since then his reactions have almost ceased and, though blind and crippled, his condition has not deteriorated since then.

$\begin{array}{rrrr}\text { Bacteriological. } & \text { I } 2.48 & \text { B.I. } & 7 \\ 8.50 & \ldots & 7 \\ \text { I.5 I } & \ldots & 8 \\ \text { I.52 } & \text {,. } & 9 \\ 2.53 & \ldots & 5 \\ 2.54 & \ldots & 2 \\ 9.54 & \text {,. } & 2\end{array}$

Z/1124. V.O. Male. 30 years. In I 934 leprosy started. In 1937 he had an early leproma, treated with hydnocarpus oil. He was irregular in attendance and returned in 1945 with nodules on ears and nose and some loss of sight. On hydnocarpus oil, his bacteriological findings became worse, but clinically he remained much the same. In October, 1949, he started Sulphetrone and in November, 1950, Dapsone $400 \mathrm{mg}$. twice weekly. He had frequent mild reactions. Nerve signs in the form of trophic lesions continued to get worse. In August, 1952, he started Isoniazid. His eyes improved slightly and reactions soon became less. He has had less tendency to trophic troubles, but I believe it is partly because he takes an intelligent and careful attitude to his hands.

$\begin{array}{lrrr}\text { Bacteriological. } & 5.49 & \text { B.I. } & 9 \\ \text { I.5I } & \text { ". } & \text { I O } \\ 5.52 & \text { ". } & 5 \\ 3.53 & \text { ". } & 3 \\ \text { II } 53 & \text { "' } & \text { I } \\ \text { I. } 54 \text { onwards } 8 \text { negatives }\end{array}$

Z/1132. E.C. Male. 50 years. I930 leprosy started. I940 small macules (history vague), started hydnocarpus oil. May, I953, showed first positive smear and continued to get worse, until in r950 he had a nodular leproma. April, 1950, daily Dapsone $200 \mathrm{mg}$. November, I950, $400 \mathrm{mg}$. twice weekly. He had many mild reactions and started Isoniazid in August, 1952, after which his reactions reduced in severity.

$\begin{array}{rrrr}\text { Bacteriological. } & \text { I } 2.49 & \text { B.I. } & 7 \\ \text { I.52 } & \text {, } & 0 \\ 2.53 & \text {, } & 4 \\ 6.54 & \text {, } & 2 \\ & 6.55 & \text {, } & \text { I }\end{array}$

Z/122. Z.U. Male. 40 years. In 1937 , he had a fairly severe leproma. Improved under hydnocarpus oil but relapsed while still on treatment. In August, I949, started Sulphetrone and in November, I950, Dapsone. In July, I952, there was little to see except wrinkling of the skin, but smears remained high. He started Isoniazid. Following that, his smears have continued to improve, but remain positive in the right ear, though it is mostly acid-fast dust that is now seen there. Clinically he has shown very little since r950.

$\begin{array}{llll}\text { Bacteriological. } & 5.49 & \text { B.I. } & 9 \\ 6.52 & \text {, } & 8 \\ & 4.54 & \text {, } & 6 \\ & \text { I.55 } & \text {,' } & 3\end{array}$

Z/299. F.N. Male. 50 years. Leprosy started about I930. Very vague early history, but he got worse on hydnocarpus treatment. In June, 1945, he came to Oji River with severe nodular leproma, which 
showed little clinical improvement under hydnocarpus oil. In April, r950, he started Dapsone $200 \mathrm{mg}$. daily and in November, 1950, $400 \mathrm{mg}$. twice weekly. In August, 1952, he started Isoniazid, after which his general health has steadily improved. His skin has remained thick and wrinkled. Bact. In spite of appearances, since r95 I the only place ever to be found bacteriologically positive was the right ear.'

$$
\begin{array}{rrrr}
\text { Bacteriological. } & 6.5 \text { I } & \text { B.I. } & 3 \\
\text { I } 2.53 & \text {." } & 2 \\
1.55 & \text { I. } & \text { I }
\end{array}
$$

Z/277. E.A. Male. 25 years. In January, 1949, he had a diffuse leproma with slight nodulation of face and swelling of feet. He had hydnocarpus oil until May, I950, when he started Dapsone maximum $200 \mathrm{mg}$. daily. In November this was changed to $400 \mathrm{mg}$. twice weekly. In August, 1952, he still showed slight nodulation of ears and general erythema. He started Isoniazid. Up to June, I955, he still has mild lepra reactions.

Bacteriological. $\quad 5 \cdot 49$

B.I. 9

2.51

6.52

, 9

$8.53 \quad$ " 7

$4.54 \quad, 6$

I. $55 \quad$, 3 